\title{
STUDI DESKRIPTIF PENGELOLAAN PEMBELAJARAN TEMATIK DALAM MENGEMBANGKAN SIKAP SPIRITUAL DI KELAS III B SD N 09 KOTA BENGKULU
}

\author{
Ety Ihwana \\ Universitas Bengkulu \\ Osa Juarsa \\ Universitas Bengkulu \\ Neza Agusdianita \\ Universitas Bengkulu
}

\begin{abstract}
This study aimed to describe the management of thematic learning in developing spiritual attitudes related to learning design, implementation and evaluation of learning spiritual attitude in class III B Elementary school number 09 Bengkulu City. The method in this research is descriptive qualitative data collection techniques such as observation, interviews, and documentation. Data analysis was performed by means of data reduction, data display, and verification. Furthermore, to test the validity of the data used extension of observation, improve endurance, triangulation techniques, and check. In this study concluded that 1) Design / thematic lesson planning done by teachers using the syllabus and lesson plans. 2) Implementation of learning is already visible management spiritual attitude. Preliminary activities through reading prayers. Core activities through the implementation of learning that teachers can use to associate the material in accordance with the management of spiritual attitudes, and activities such as closing prayer after completion of learning. 3) Evaluation of management of spiritual attitudes of teachers conducted in a way to make observations on the spiritual attitude of students daily from early learning to finish. Evaluation of teachers carried out using observation without special note.
\end{abstract}

Key words: Management, thematic learning, spiritual attitude

\section{PENDAHULUAN}

Pendidikan merupakan unsur utama dalam pengmbangan manusia Indonesia seutuhnya. Oleh karenanya, pendidikan berperan penting dalam pembentukan karakter. Sekolah sebagai institusi pendidikan formal bukanlah sekedar mendidik anak-anak bangsa untuk cerdas secara intelektual dan terampil dari segi keahlian, tetapi pada saat yang sama juga harus bersikap kuat dalam kepribadian yang melahirkan sikap dan tindakan yang serba utama sebagai manusia religius dan berbudaya luhur (Nashir, 2013 :06).

Hal ini sejalan dengan landasan negara kita yaitu Pancasila dimana sila pertama menyatakan bahwa Negara kita berdasarkan atas Ketuhanan Yang Maha Esa. Intinya adalah negara kita merupakan negara religius yang menjadikan sila pertama dari Pancasila tersebut sebagai inti dari keempat sila lainnya. Karakter religius merupakan landasan utama dari karakter yang lain, seperti yang diungkapkan Suhammijaya dalam Maesaroh (2015:34) yang mengatakan : "Karakter harus mempunyai landasan yang kokoh dan jelas. Tanpa landasan yang jelas, sikap tidak berarti apa-apa. Oleh karenanya, fundamen atau landasan dari pendidikan sikap itu tidak lain haruslah agama." Pengembangan karakter seharusnya menjadi perhatian khusus setiap sekolah demi tercapainya 
pendidikan karakter yang optimal. Pendidikan sikap harus diletakkan secara keseluruhan dengan pembangunan karakter bangsa (Nation and character building) dan dalam kaitan ini betapa penting fungsi lembaga pendidikan sebagai bagian strategis dari strategi kebudayaan dalam membangun bangsa (Nashir, 2013: 07).

Sebagaimana tercantum dalam tujuan pendidikan nasional yang bersumber dari nilai Pancasila dirumuskan dalam UU Nomor 20 Tahun 2003 Pasal 3, yang merumuskan bahwa pendidikan nasional berfungsi mengelola kemampuan dan membentuk watak serta peradaban bangsa yang bermartabat dalam rangka mencerdaskan kehidupan bangsa, bertujuan untuk berkembangnya potensi peserta didik agar menjadi manusia yang beriman dan bertaqwa kepada Tuhan Yang Maha Esa, berakhlak mulia, sehat, berilmu, cakap, kreatif, mandiri, dan menjadi warga negara yang demokratis dan bertanggung jawab (Fathurrohman, 2013 : 08). Tujuan yang terkandung dalam pasal I UUD Sisdiknas tahun 2003 agar peserta didik secara aktif mengelola potensinya yaitu kekuatan spiritual keagamaan, pengendalian diri, kepribadian, kecerdasan, akhlak mulia dan terampil.

Sikap spiritual yang ada dalam kurikulum 2013 tercantum dalam muatan Kompetensi Inti-1 (KI-1) menjadi wadah dalam mengelola sikap spiritual. Penerapan sikap spiritual (KI-1) ini termuat dalam proses pembelajaran dan di luar pembelajaran. Pembelajaran yang berorientasi sikap spiritual diharapkan mampu mengintegrasikan semangat keagamaan dalam pembelajaran. Pembelajaran yang bermuatan spiritual yang sebenarnya adalah menjawab persoalan bangsa mengenai persoalan moralitas. Oleh karena itu, terjadi keselarasan antara kurikulum 2013 yang mengelola sikap spiritual dengan pembelajaran spiritual sebagai upaya mewujudkan generasi yang cerdas komprehensif.

Permasalahan yang terjadi adalah tidak semua guru dapat mengelola sikap spiritual dalam pembelajaran. Padahal rumusan KI-1 (Sikap Spiritual) pada kurikulum 2013 seharusnya diterapkan sebagai wujud pendidikan sikap. Guru masih cenderung hanya menguasai cara mengajar kognitif saja tanpa menyeimbangkan dengan unsur afektif.

Berdasarkan observasi dan wawancara yang peneliti lakukan di SD N 09 Kota Bengkulu, di sini penegakkan akhlak mulia yang spiritual menjadi perhatian tersendiri untuk menanamkan nilai-nilai baik pada siswa demi terciptanya generasi penerus yang lebih beriman dan berbudaya, sebagai pendidik yang mempunyai tanggung jawab guru harus mempunyai ketegasan dalam menanamkan nilainilai spiritual sebagai bentuk ketakwaan terhadap Tuhan Yang Maha Esa dan berakhlak mulia kepada sesama. Contohnya adalah adanya kegiatan shalat dhuha setiap hari jumat, dan shalat dhuhur berjamaah. Poster-poster tentang Asmaul Husna juga terdapat pada bagian luar sekolah, simbol-simbol agamis di dalam kelas juga tak tertinggal. Selain itu, penerapan Kurikulum 2013 di SD N 09 Kota Bengkulu ini juga tetap diberlakukan hingga sekarang untuk menciptakan generasi yang lebih inovatif dan kreatif. Kurikulum 2013 juga memuat Kompetensi Inti 1 (KI-1) yakni sikap spiritual yang menunjang pengembangan sikap spiritual.

Peneliti melihat bahwa wali kelas III selalu menanamkan prinsip beriman kepada Tuhan Yang Maha Esa dan menanamkan sikap-sikap sosial sebagai bentuk kepedulian terhadap sesama. Pengelolaan sikap spiritual dapat dikembangkan dalam pembelajaran tematik sesuai dengan rumusan KI-1 dalam setiap mata pelajarannya.

Pengembangan sikap spiritual ini dapat termuat dalam desain/perencanaan pembelajaran yang dibuat guru berupa silabus dan RPP. Guru di SD N 09 Kota Bengkulu menggunakan silabus dan RPP sebagai pedoman perencanaan pembelajaran. Selain itu, guru juga melaksanakan pembelajaran di kelas dengan mengelola sikap dengan mengaitkan setiap materi yang ada. Tak lupa guru kerap memberikan nasehat seperti berteman tanpa membedakan agama, karena di dalam kelas III B juga terdapat siswa beragama non-muslim. Kemudian, menasehati untuk selalu bersyukur terhadap nikmat yang diberikan Tuhan dan senantiasa memelihara 
hubungan baik dengan sesama makhluk ciptaan Tuhan Yang Maha Esa. Tahap berikutnya dengan evaluasi sikap, maka pengelolaan sikap spiritual dalam pembelajaran akan lebih optimal.

Didukung dengan kajian empiris yang telah meneliti mengenai sikap spiritual siswa SD. Fajiria Hidayatun Marfu'ah, 2014 dalam penelitiannya yang berjudul "Pembelajaran Pendidikan Agama Islam dan Budi Pekerti Muatan Spiritual dalam Kurikulum 2013 Kelas IV SD Bantul Timur Kabupaten Bantul”. Hasil dari penelitian ini adalah pelaksanaan pembelajaran PAI dan Budi Pekerti termuat sikap spiritual terbagi dalam tiga aspek yaitu perencanaan, pelaksanaan, dan evaluasi, hasil pembelajaran PAI dan Budi Pekerti yang bermuatan spiritual telah memenuhi indikator pencapaian sikap spiritual dalam pembelajaran. Berdasarkan hal tersebut, peneliti akan mengkaji pengelolaan sikap spiritual dalam pembelajaran pada salah satu tema yakni tema Energi dan perubahannya dalam kurikulum 2013 kelas III. Tentu saja, tujuannya adalah selain tidak sama persis dengan peneliti terdahulu, juga ingin menambah wawasan dan pemahaman kajian tentang sikap spiritual dalam kurikulum 2013.

Berdasarkan hal di atas, maka penelitian dalam skripsi ini mengambil judul : Studi Deskriptif Pengelolaan Pembelajaran Tematik dalam Mengembangkan Sikap Spiritual di kelas III B SD N 09 Kota Bengkulu. Berdasarkan latar belakang di atas, maka permasalahan umum penelitian ini adalah "Bagaimana Pengelolaan Pembelajaran Tematik dalam mengembangkan Sikap Spiritual di kelas III B SD N 09 Kota Bengkulu?" Rumusan khusus permasalahan penelitian ini adalah : 1 . Bagaimana cara guru mendesain pembelajaran tematik untuk mengembangkan sikap spiritual? 2. Bagaimana cara guru melaksanakan pembelajaran tematik yang dilakukan guru dalam mengembangkan sikap spiritual? 3. Bagaimana cara guru melakukan evaluasi sikap spiritual dalam pembelajaran tematik ?. Agar tidak menyimpang dari permasalahan yang akan dikaji dan dibahas dalam penelitian ini, maka hanya difokuskan pada:1. Pembelajaran tematik Tema 7 (Energi dan Perubahannya) Subtema 1 (Sumber
Energi) dengan mata pelajaran yang termuat adalah PPKn, Bahasa Indonesia dan Matematika. 2. Pengelolaan dalam penelitian ini dibatasi pada aspek desain/perencanaan, pelaksanaan,dan evaluasi. 3. Desain pembelajaran dibatasi berupa silabus dan RPP. Pada pelaksanaan pembelajaran dibatasi pada kegiatan pendahuluan, inti, dan penutup. Evaluasi sikap spiritual dibatasi pada teknik evaluasi sikap, bentuk instrumen, dan pelaksanaan evaluasi sikap. 4. Sikap spiritual yang dimaksud dalam penelitian ini dibatasi pada proses pembelajaran seperti berdoa sebelum dan sesudah melakukan sesuatu, selalu menerima penugasan dengan sikap terbuka, mengakui kebesaran Tuhan dalam menciptakan alam semesta, berserah diri (bertawakal) kepada Tuhan setelah berikhtiar atau melakukan usaha, berteman tanpa membedakan agama, perilaku menerima perbedaan karakteristik sebagai anugrah Tuhan, mengucapkan syukur ketika berhasil mengerjakan sesuatu, dan berdoa ketika pelajaran selesai.

Tujuan umum yang hendak dicapai dalam penelitian ini adalah : "Mendeskripsikan pengelolaan pembelajaran tematik dalam mengembangkan sikap spiritual di kelas III B SD N 09 Kota Bengkulu" Tujuan khusus dalam penelitian ini adalah : 1. Mendeskripsikan cara guru mendesain pembelajaran tematik untuk mengembangkan sikap spiritual 2. Mendeskripsikan cara guru melaksanakan pembelajaran tematik yang dilakukan guru dalam mengembangkan sikap spiritual. 3. Mendeskripsikan cara guru melakukan evaluasi sikap spiritual dalam pembelajaran di tematik.

\section{METODE}

Jenis penelitian yang digunakan dalam penelitian ini adalah deskriptif kualitatif. Hal ini sesuai dengan tujuan penelitian bahwa metode deskriptif digunakan untuk mendeskripsikan pengelolaan pembelajaran tematik dalam mengembangkan sikap spiritual pada siswa dalam proses pembelajaran tematik di kelas III B SD N 09 Kota Bengkulu. Menurut Winarni (2011 : 38) penelitian deskriptif adalah penelitian 
yang diarahkan untuk memberikan gejala-gejala, fakta-fakta, kejadian- kejadian secara sistematis dan akurat, mengenai sifat-sifat populasi atau daerah tertentu.

Metode penelitian ini dinamakan penelitian kualitatif naturalistik. Istilah naturalistik menunjukkan bahwa pelaksanaan penelitian ini memang terjadi secara alamiah, apa adanya, dalam situasi nomal yang dimanipulasi keadaan dan kondisinya, menekan pada deskripsi alami. Penelitian ini dilaksanakan di SD N 09 Kota Bengkulu yang beralamatkan di Jalan Soekarno Hatta Kelurahan Anggut Atas Kecamatan Ratu Samban Kota Bengkulu. Peneliti memilih lokasi ini karena sekolah ini menerapkan kurikulum 2013 yang menekankan sikap spiritual sebagai pendidikan sikap di sekolah. Data yang digunakan dalam penelitian ini adalah data primer dan data sekunder, yaitu:

\section{(a) Data Primer}

Pada penelitian ini data primer diperoleh melalui pedoman observasi untuk mengamati langsung aktivitas guru dan aktivitas siswa di kelas III B pada pembelajaran tematik, yaitu cara guru mendesain pembelajaran, melaksanakan pembelajaran dan mengevaluasi sikap spiritual.

(b)Data sekunder

Data sekunder merupakan data yang sifatnya pendukung data primer berkaitan dengan pembelajaran tematik dalam mengelola sikap spiritual di kelas III B SD N 09 Kota Bengkulu. Data sekunder pada penelitian ini berupa data wawancara dengan guru dan kepala sekolah, dan dokumentasi (silabus dan RPP) yaitu berupa cara guru dalam mengelola pembelajaran tematik dalam mengembangkan sikap spiritual. Subjek penelitian ini adalah wali kelas III B, siswa kelas III B dan kepala sekolah di SD N 09 Kota Bengkulu.

Teknik pengumpulan data dalam penelitian ini melalui observasi, wawancara, dan dokumentasi. Analisis data adalah proses mencari dan menyusun data secara sistematis yang diperoleh dari hasil observasi, wawancara, dan dokumentasi. Analisis data dilakukan dengan cara mengumpulkan seluruh data yang didapat dari hasil observasi, wawancara dan dokumentasi lalu dibaca kembali, ditelaah kembali dan dipelajari kembali. Sehingga dari data tersebut, peneliti dapat mengorganisasikan data, menjabarkan data, menggabungkan data dan menyusun data sehingga mudah dipahami oleh peneliti maupun orang lain. Dalam penelitian kualitatif ini terdapat empat alur kegiatan untuk mendapatkan data yang valid, yaitu: Pengumpulan data, reduksi data, penyajian data, dan penarikan kesimpulan.

Humberman dan Miles dalam Sugiyono (2014:246) melukiskan siklus dari langkahlangkah analisis yang dilakukan yaitu pengumpulan data (data collection), reduksi data (data reduction), penyajian data (display data), dan penarikan kesimpulan (verifiction data). Kemudian keabsahan data dalam penelitian ini valid dapat diperoleh dengan melakukan uji kredibilitas terhadap data hasil penelitian sesuai dengan prosedur uji kredibilitas data dalam penelitian kualitatif. Dalam penelitian ini keabsahan data menggunakan perpanjangan pengamatan, peningkatan ketekunan, triangulasi dan member check.

\section{HASIL}

\section{Deskripsi Hasil Penelitian}

Penelitian yang berjudul pengelolaan pembelajara tematik dalam mengembangkan sikap spiritual di kelas III B. Guru yang menjadi subjek penelitian adalah seorang guru senior yang dikenal dengan keaktifannya di sekolah. Penelitian ini dilaksanakan kurang lebih selama satu bulan di SD N 09 Kota Bengkulu. Pengembangan sikap spiritual tergambar melalui perencanaan, pelaksanaan dan evaluasi pembelajaran tematik. Data diperoleh melalui metode observasi, wawancara, dan dokumentasi dengan menggunakan pedoman observasi dan pedoman wawancara. Data yang diperoleh direduksi untuk mendapatkan data yang dibutuhkan, kemudian dilakukan display (penyajian) data. Hasil penelitian tentang pengelolaan pembelajaran tematik dalam mengembangkan sikap spiritual di Kelas III B SD N 09 Kota Bengkulu, dapat dideskripsikan peraspek pada deskripsi berikut: 
Deskripsi hasil tentang desain/perencanaan pembelajaran dalam pengelolaan sikap spiritual

Berdasarkan rumusan masalah pertama tentang desain/perencanaan pembelajaran tematik dalam pengelolaan sikap spiritual di kelas III B SD N 09 Kota Bengkulu dapat dideskripsikan sebagai berikut :

\section{Silabus}

Silabus merupakan acuan dalam mengelola RPP yang memuat identitas mata pelajaran seperti KI (Kompetensi Inti), KD (Kompetensi Dasar), indikator, materi, kegiatan pembelajaran, evaluasi, alokasi waktu dan sumber belajar. Di dalam silabus yang dibuat Guru LT terdapat mata pelajaran PPKn, Bahasa Indonesia, dam Matematika.

\section{Rencana Pelaksanaan Pembelajaran (RPP)}

RPP merupakan Pengelolaan dari silabus yang dibuat untuk dijadikan pedoman dalam melaksanakan pembelajaran. Seperti halnya dalam Pengelolaan sikap spiritual Guru LT juga menggunakan RPP sebagai panduan/pedoman. Sejalan dengan pernyataan Guru LT pada saat wawancara seperti berikut:

"Seperti dalam RPP itu ada pada langkahlangkah pembelajaran sebelum belajar membaca doa terlebih dahulu, begitu pula sesudah belajar juga membaca doa. Nah pada RPP itu kan tertulis, jadi sikap spiritual itu tertulis atau tidak itu kita terapkan seperti materi tema 7 itu tentang pelestarian energi, kenapa kita perlu melestarikannya? Ya karena energi yang diciptakan Allah ini terbatas. Setiap pelajaran itu spiritualnya kita masukkan terus di dalam pembelajaran."

\section{Deskripsi hasil tentang pelaksanaan pembelajaran tematik dalam mengelola sikap spiritual di kelas III B SD N 09 Kota Bengkulu}

Berdasarkan rumusan masalah kedua tentang pelaksanaan pembelajaran tematik dalam mengelola sikap spiritual di kelas III B SD N 09 Kota Bengkulu dapat dideskripsikan sebagai berikut:

\section{a. Kegiatan Pendahuluan}

1) Menyiapkan siswa belajar seperti membaca doa sebelum melaksanakan pembelajaran. Guru mencontohkan dan menumbuhkan perilaku berdoa sebelum dan sesudah melakukan kegiatan

2) Melakukan apersepsi pada keseluruhan siswa yang mengarah pada pengembangan sikap spiritual

3) Menjelaskan tujuan pembelajaran yang mengarah pada pengembangan sikap spiritual

4) Penyampaian materi atau tema sekaligus pengelolaan sikap spiritual

\section{b. Kegiatan Inti}

5) Mengarahkan siswa dalam kegiatan mengamati seperti kegiatan membaca, mendengar,menyimak, melihat (tanpa atau dengan alat) guru menanamkan perilaku selalu menerima penugasan dengan sikap terbuka (bersyukur)

6) Memunculkan minat siswa dalam kegiatan menanya tentang apa yang tidak dipahami dari apa yang diamati atau pertanyaan untuk mendapatkan informasi tambahan tentang apa yang diamati

7) Melibatkan siswa dalam mencari informasi yang luas secara bersama-sama tanpa membedakan agama (toleransi beragama)

8) Pendekatan, media dan sumber belajar yang di gunakan dalam mendukung pengelolaan sikap spiritual

9) Berinteraksi dengan siswa dan memfasilitasi siswa berinteraksi dengan siswa lainnya.tanpa membedakan agama (toleransi beragama)

10) Membimbing siswa dalam mengumpulkan informasi/eksperimen. Guru dapat mengelola sikap spiritual seperti memelihara hubungan baik dengan sesama umat ciptaan Tuhan Yang Maha Esa.

11) Memfasilitasi siswa agar menanggapi, ataupun berpendapat dalam kegiatan belajar

12) Melibatkan siswa dalam kegiatan musyawarah/mufakat. Guru menanamkan sikap memelihara hubungan baik dengan sesama umat ciptaan Tuhan 
13) Guru membimbing siswa dalam mengolah informasi yang telah dikumpulkan. guru menanamkan perilaku selalu menerima penugasan dengan sikap terbuka (bersyukur)

14) Memotivasi siswa agar bersikap spiritual

15) Mengajarkan siswa mengenai sikap spiritual

16) Siswa melaksanakan doa setelah selesai pembelajaran

Deskripsi hasil tentang evaluasi sikap spiritual dalam pembelajaran tematik di kelas III B SD N 09 Kota Bengkulu

Berdasarkan rumusan masalah yang ketika yakni evaluasi sikap spiritual dalam pembelajaran tematik di kelas III B SD N 09 Kota Bengkulu dapat dideskripsikan sebagai berikut.

Berdasarkan wawancara, Guru LT mengatakan bahwa teknik evaluasi sikap yang ia gunakan dalam menilai sikap yaitu dengan melakukan pengamatan setiap gerak-gerik siswa setiap harinya dalam aspek spiritualnya. Berdasarkan observasi Guru melakukan evaluasi sikap dengan pengamatan, tidak terlihat Guru LT membawa catatan khusus untuk mencatat evaluasi sikap yang dilakukan.

Berdasarkan wawancara, Guru LT mengungkapkan instrumen evaluasinya bisa dengan soal-soal dalam buku tema. Dengan soal siswa mudah mengerti. Tetapi untuk mengamati sikap mereka tentunya dengan pengamatan dengan lembar observasi. Guru LT mengaku setiap sikap spiritual siswa ia amati dan perhatikan. Berdasarkan observasi, lembar observasi yang terdapat di RPP tidak digunakan Guru LT dalam melakukan pengamatan seharihari.

Berdasarkan wawancara yang diungkapkan

Guru LT bahwa ia melakukan pengamatan sikap setiap hari, tetapi merekapnya dalam lembar evaluasi dilakukan satu minggu sekali. Berdasarkan observasi, pengamatan yang dilakukan Guru LT terlihat setiap hari, seperti selalu memperhatikan siswa yang sedang berdoa apakah sudah berdoa dengan sikap yang baik atau belum. Saat melakukan ibadah apakah rajin atau tidak, mengamati siswa dalam berperilaku bersyukur kepada Tuhan dalam setiap melaksanakan proses pembelajaran setiap harinya.

\section{PEMBAHASAN}

Desain/perencanaan pembelajaran tematik dalam mengelola sikap spiritual di kelas III B SD N 09 Kota Bengkulu

Berdasarkan analisis data yang diperoleh dari triangulasi pengumpulan data dokumentasi, wawancara dan observasi yang telah peneliti lakukan maka diperoleh hasil sebagai berikut :

\section{Silabus}

Komponen silabus yang dibuat oleh guru belum terpenuhi semua karena tidak tercantum KI (Kompetensi Inti) dalam muatan silabus. Komponen silabus secara lengkap meliputi kompetensi inti, kompetensi dasar, materi pembelajaran, kegiatan pembelajaran, evaluasi, alokasi waktu, dan sumber belajar (Kemdikbud 2013:12). Secara umum, untuk setiap materi pokok pada setiap silabus terdapat $4 \mathrm{KD}$ sesuai dengan aspek KI (sikap kepada Tuhan, diri sendiri dan terhadap lingkungan, pengetahuan, dan keterampilan). Untuk mencapai $4 \mathrm{KD}$ tersebut, di dalam silabus dirumuskan kegiatan peserta didik secara umum dalam pembelajaran berdasarkan standar proses. Kegiatan peserta didik ini merupakan rincian dari eksplorasi, elaborasi, dan konfirmasi, yakni: mengamati, menanya, mengumpulkan informasi, mengasosiasi/ mengolah informasi, dan mengkomunikasikan. Silabus yang digunakan guru berdasarkan silabus yang diberikan oleh pihak sekolah, komponen saintifik tidak terlihat dalam kegiatan peserta didik dalam silabus.

\section{Rencana Pelaksanaan Pembelajaran (RPP)}

Dalam RPP yang dibuat oleh guru dirumuskan berdasarkan buku guru. Seperti halnya KI yang termuat dalam RPP yakni dari 
KI-1 hingga KI-4. KI-1 tentang sikap spiritual, KI-2 tentang sikap sosial, KI-3 tentang pengetahuan, dan KI-4 tentang keterampilan. Kompetensi Inti merupakan gambaran secara kategorial mengenai kompetensi dalam aspek sikap, pengetahuan, dan keterampilan yang harus dipelajari siswa untuk suatu jenjang sekolah, kelas, dan mata pelajaran (Kemdikbud :2013). Karena dalam RPP termuat aspek KI secara lengkap dari KI-1 hingga KI-4 maka dalam RPP guru terdapat aspek sikap spiritual.

Guru menentukan KD berdasarkan KI1(sikap spiritual), KI-2 (sikap sosial), KI-3 (pengetahuan), KI-4 (keterampilan). Guru telah merumuskan KD dari semua KI. Menurut Kemdikbud (2013) secara umum untuk setiap materi pokok terdapat $4 \mathrm{KD}$ sesuai dengan aspek KI. Guru hendaknya menetukan KD berdasarkan semua KI, hal ini dikarenakan esensi dari kurikulum 2013 adalah keseimbangan antara sikap (spiritual dan sosial), pengetahuan, dan keterampilan. Hal ini sesuai dengan langkahlangkah menetukan KD menurut Abidin (2014:299) bahwa baik untuk kompetensi inti maupun kompetensi dasar hal yang harus dilakukan adalah menetukan terlebih dahulu KI-3 dan KI-4 sebelum menentukan KD-1 dan KD-2. Guru telah merumuskan KD dari rumusan KI-1 hingga KI-4 sehingga KD yang terdapat pada RPP guru termuat aspek sikap spiritual.

\section{Pelaksanaan pembelajaran tematik dalam mengelola sikap spiritual di kelas III B SD N 09 Kota Bengkulu}

\section{a. Kegiatan Pendahuluan}

Kegiatan pendahuluan yang dilakukan guru diawali dengan menyiapkan peserta didik untuk siap melaksanakan pembelajaran. Hal-hal yang dilakukan guru seperti menyapa peserta didik dan memberi salam ketika memasuki kelas, guru selalu menerapkan kegiatan membaca doa sbelum kegiatan pembelajaran dimulai. Sikap berdoa yang baik juga guru terapkan supaya siswa lebih serius dalam berdoa. Menurut Trianto (2009:48) bahwa kegiatan menyiapkan siswa bertujuan untuk menarik siswa, memusatkan perhatian siswa, pada pokok pembicaraan dan mengingatkan kembali pada hasil belajar yang telah dimilkinya yang relevan dengan pokok pembicaraan yang dipelajari.

\section{b. Kegiatan Inti}

Pada kegiatan inti, banyak kegiatan yang telah dilakukan guru sesuai dengan langkahlangkah pendekatan Saintifik yakni mengamati, menanya, mengumpulkan informasi, mengolah informasi, dan mengkomunikasikan. Kegiatan mengamati dilakukan guru dengan mengarahkan siswa membaca buku teks pada buku guru. Kegiatan mengamati juga dilaksanakan dengan kegiatan melihat gambar dan menyimak teman membaca teks percakapan. Menurut Kemdikbud (2013) kegiatan mengamati salah satunya dapat dilakukan dengan menyimak. Menurut Winarni (2012:21) keterampilan mengobservasi (mengamati) merupakan keterampilan yang dikembangkan dengan segenap indra/panca indra dan alat bantu indra untuk memperoleh informasi serta mengidentifikasi nama/sikapistik dari suatu objek atau kejadian. Pada kegiatan mengamati guru mengelola sikap spiritual dengan mengaitkan materi- materi dalam kegiatan tersebut seperti membaca teks tentang melestarikan sumber energi, siswa diarahkan agar menghemat sumber energi yang diciptkan Tuhan sebagai bentuk rasa syukur.

\section{c. Kegiatan Penutup}

Berdasarkan hasil penelitian, guru melakukan kegiatan penutup melalui beberapa tahap yakni menyimpulkan pembelajaran, melakukan refleksi, menyebutkan rencana pembelajaran untuk pertemuan yang akan datang, memberi motivasi siswa tentang sikap spiritual dan membaca doa setelah selesai pembelajaran.

Kegiatan menyimpulkan pembelajaran telah guru laksanakan, hanya saja guru kurang terlalu melibatkan siswa dalam menyimpulkan. Bahkan beberapa pertemuan guru tidak menyimpulkan pembelajaran. Menurut Anitah (2009:4.35) bahwa kegiatan merangkum (menyimpulkan) dan membuat ringkasan sebaiknya dilakukan siswa di bawah bimbingan guru sehingga pada saat siswa 
membuat rangkuman atau kesimpulan atau ringkasan itu salah atau kurang sempurna, guru dapat membetulkan atau menyempurnakan rangkman/kesimpulan/ringkasan yang dibuat siswa.

\section{Evaluasi sikap spiritual dalam pembelajaran tematik di kelas III B SD N 09 Kota Bengkulu}

Evaluasi sikap spiritual berkaitan dengan evaluasi sikap siswa. Dalam kurikulum 2013 evaluasi sikap menjadi aspek penting tanpa menyampingkan aspek pengetahuan dan keterampilan. Sikap yang dinilai adalah sikap spiritual dan sikap sosial. Evaluasi sikap dapat dilakukan menggunakan teknik observasi, evaluasi diri, evaluasi antarteman, dan jurnal (Kemdikbud A, 2014 : 81).

Berdasarkan hasil penelitian, guru melaksanakan evaluasi sikap dengan teknik observasi saja, terlebih lagi guru tidak menggunakan catatan khusus saat melakukan evaluasi, hanya saat merekapnya guru menggunakan lembar observasi yang instrumennya tertera di RPP. Waktu melaksanakan evaluasi sikap adalah saat pembelajaran berlangsung dari awal hingga akhir pembelajaran. Guru mengamati sikap siswa saat melakukan diskusi, presentasi di depan, saat mengerjakan tugas dan saat berinteraksi dengan teman dan guru.

\section{SIMPULAN}

Berdasarkan hasil penelitian dan pembahasan tentang Pengelolaan sikap spiritual pada siswa dalam pembelajaran tematik di SD N 09 Kota Bengkulu maka, dapat disimpulkan bahwa sudah mulai tampak pengelolaan sikap spiritual melalui pembelajaran tematik di kelas III B SD N 09 Kota Bengkulu.

1. Desain/perencanaan pembelajaran tematik yang dibuat oleh guru yaitu guru berupa silabus dan RPP. Tidak tercantum aspek sikap dalam silabus dan tidak tercantum KI dalam silabus. Guru menggunakan RPP yang bersumber dari buku guru. Termuat aspek karaker spiritual dalam RPP yakni pada rumusan $\mathrm{KI}$, KD, Langkah- langkah pembelajaran, dan evaluasi.

2. Pelaksanaan pembelajaran sudah terlihat pengelolaan sikap spiritual. Kegiatan pendahuluan sudah mengelola sikap spiritual melalui kegiatan membaca doa. Kegiatan inti sudah menunjukkan pengelolaan sikap spiritual melalui pelaksanaan pembelajaran yang digunakan guru yakni dengan mengaitkan materi-materi yang sesuai dengan pengelolaan sikap spiritual. Kegiatan penutup berupa membaca doa setelah selesai pembelajaran.

3. Evaluasi Pengelolaan sikap spiritual yang dilaksanakan guru dengan cara melakukan pengamatan pada sikap spiritual siswa sehari-hari dari awal pembelajaran hingga selesai. Evaluasi yang guru laksanakan hanya menggunakan teknik observasi tanpa catatan khusus.

\section{SARAN}

Berdasarkan hasil penelitian tentang pengelolaan sikap spiritual dalam pembelajaran tematik di SD N 09 Kota Bengkulu maka, disarankan sebagai berikut:

1. Saran untuk guru dalam mengelola sikap spiritual meliputi:

a. Desain Pembelajaran, sebaiknya guru mencantumkan KI dalam silabus sesuai dengan ketentuan kurikulum. Kemudian, guru hendaknya menganalisis saat membuat RPP tidak hanya mengambil dari buku guru. Pengelolaan sikap spiritual dalam perencanaan sebaiknya lebih ditingkatkan terutama dalam kegiatan inti.

b. Pelaksanaan Pembelajaran, setelah membuat perencanaan yang tepat untuk pengelolaan sikap spiritual, disarankan untuk meningkatkan pengelolaan sikap spiritual pada kegiatan pendahuluan, inti, dan penutup.

c. Evaluasi, guru sebaiknya mengembangkan evaluasi otentik untuk 
menilai sikap spiritual. Hal ini akan membantu guru untuk mengontrol sikap siswa, kecakapan siswa dalam melakukan sesuatu dan menentukan tindak lanjut yang tepat terhadap sikap tersebut. Evaluasi sikap yang baik bukan hanya teknik observasi saja, melainkan adanya evaluasi antarteman, evaluasi diri dan jurnal dari guru. Disarankan untuk melakukan tidak lanjut yang berhubungan dengan pengelolaan sikap spiritual.

2. Saran untuk peneliti selanjutnya

Diharapkan peneliti selanjutnya untuk dapat meneliti pengelolaan sikap spiritual diterapkan pada tema-tema yang lain dan kelas- kelas yang lain.

\section{DAFTAR PUSTAKA}

Abidin, Yunus. 2014. Desain Sistem Pembelajaran dalam Konteks Kurikulum 2013. Bandung: PT Refika Aditama.

Amin, Saiffudin. 2013. Tren Spiritual Millenium Ketiga. Banten: Ruhama.

Anitah, Sri. 2009. Strategi Pembelajaran di SD. Jakarta : Universitas Terbuka.

Aqib, Zainal. 2015. Pendidikan Sikap di Sekolah Membangun Sikap dan Kepribadian. Bandung: YRAMA WIDYA

Fathurrohman, Pupuh. 2013. Pengelolaan Pendidikan Karakter. Bandung : PT Refika Aditama

Gunawan, Heri. 2012. Pendidikan Sikap Konsep dan Implementasi. Bandung : Alfabeta

Hernawan, Asep 2006. Pengembangan Kurikulum dan Pembelajaran. Bandung : Alfabeta.

Kementrian Pendidikan dan Kebudayaan. 2013. Materi Pelatihan Guru Implemantasi Kurikulum 2013. Jakarta : Kemendikbud

Kementrian Pendidikan dan Kebudayaan A. 2014. Materi Pelatihan Guru
Implemantasi Kurikulum 2013.Jakarta : Kemendikbud

Kementrian Pendidikan dan Kebudayaan B, 2014. Panduan Evaluasi Sikap. Jakarta : Kemendikbud

Khasanah, Muhimmatun. Pembentukan Sikap Spiritual Siswa pada Pembelajaran PAI dan Budi Pekerti di Kelas VII G SMP N 1 Imogiri Bantul Yogyakarta. Skripsi. UIN Sunan Kalijaga Yogyakarta.

Komalasari. 2013. Strategi Pembelajaran Berorienstasi Stadra Proses Pendidikan. Jakarta : Kencana Prenada Media Group

Kurniasih A, Imas. 2014. Implementasi Kurikulum 2013 Konsep \& Penerapan. Surabaya : Kata Pena

Kurniasih B, Imas. 2014. Sukses Mengimplementasikan Kurikulum 2013. Surabaya: Kata Pena

Maesaroh, Chusnul. 2015 Manajemen Kurikulum Takhasus Untuk Mengembangkan Karakter Religius Siswa di SD Hj. Isriati Baiturrahman 2 Semarang. Skripsi. UIN Walisongo Semarang.

Nashir,Haedar. 2013. Pendidikan Sikap Berbasis Agama dan Budaya. Yogyakarta : Multi Presindo.

Nata, Abbidun. 2003. Pendidikan Spiritual dalam Tradisi Keislaman. Bandung: Angkasa.

Permendikbud, Nomor 81A Tahun 2013 Lampiran IV tentang Implementasi Kurikulum Pedoman Umum Pembelajaran

Permendikbud, Undang-undang No 65 Tahun 2003 tantang Standar Proses Pendidikan Dasar dan Menengah.

Sugiyono. 2014. Memahami Penelitian kualitatif,. Bandung: Alfabeta

Tim Penyusun. 2015. Panduan Penyusunan Skripsi. Bengkulu:. FKIP UNIB.

Trianto. 2009b. Mendesain Model Pembelajaran Inovatif Progresif. Jakarta :Kencana Prenada Medi Group 
Ety Ihwana, Osa Juarsa, \& Neza Agusdianita

Winarni, EW. 2011. Penelitian pendidikan. Bengkulu : FKIP UNIB

Winarni, Widi. 2012. Inovasi Dalam Pembelajaran IPA. Bengkulu : Unit penerbitan FKIP UNIB.

\section{Sumber lain :}

Smith dan ragan. 2010. Desain pembalajaran. http://ervindasabila.blogspot.com/2010/07/ desain- pembelajaran.html.Diunduh pada tanggal 18 Januari 2016. 